\title{
Effect of resistant and susceptible soybean cultivars on the attraction of egg parasitoids under field conditions.
}

\author{
Mirian F. F. Michereff ${ }^{1}$, Miguel Michereff Filho ${ }^{2}$, Miguel Borges ${ }^{1}$, Raúl A. \\ Laumann ${ }^{1}$, Ivone R. Diniz ${ }^{3}$, Maria Carolina Blassioli-Moraes ${ }^{1}$ \\ ${ }^{1}$ Embrapa Recursos Genéticos e Biotecnologia - Cenargen, Parque Estação Biológica-W5 Norte, \\ CEP 70770-900 Brasília, DF, e-mail: mirianfm@terra.com.br; ${ }^{2}$ Embrapa Hortaliças - Rodovia BR \\ 060, Km 09, Gama, DF, ${ }^{3}$ Universidade de Brasília - UnB, Departamento de Ecologia, Campus \\ Darcy Ribeiro, Brasília, DF.
}

The association of resistant crop varieties and biological pest control has great potential for pest management, as resistant cultivars may affect herbivores' population dynamics by interfering with their biology and search behavior for host plants. In addition, resistant varieties can also affect the efficiency of natural enemies. The aims of this work were to evaluate the influence of the soybean cultivars Dowling (resistant), IAC 100 (resistant) and Silvânia (susceptible) under field conditions on: i) the abundance of parasitoids in the Platygastridae family and the stink bug Euschistus heros and ii) the parasitism of stink bug eggs by these natural enemies. There was no difference between cultivars in stink bug distribution in the field. The parasitoids Telenomus podisi, Trissolcus teretis, Tr. urichi and Tr. brochymenae emerged from the sentinel eggs of E. heros, and $T$. podisi was the most abundant species observed during the reproductive stage R6. The cultivars Dowling and IAC 100 attracted a higher number of platygastrid parasitoids, T. podisi and Tr. Basalis. The abundance of these parasitoids during the period from R1 to R7 might have being sufficient to control the stink bug population. These results suggest that the cultivars Dowling and IAC100 have important attributes that should be taken into account in the implementation and development of new cultivars in breeding programs that aim to obtain plants more resistant to stink bugs and more attractive to natural enemies.

Key words: Plant resistance, soybean crop, biological control.

Finantial support: CNPq, Embrapa, FAP-DF 